\title{
Nisin-loaded bacterial cellulose: evaluation of its antimicrobial activity stability
}

Gabriela R. dos Santos ${ }^{1}$, Victória Soares Soeiro ${ }^{1}$, Janaína Artem Ataide ${ }^{2}$, André Moreni Lopes ${ }^{2}$, Priscila Gava Mazzola $^{2}$, Denise Grotto ${ }^{3}$, Angela F. Jozala ${ }^{1, *}$

*Corresponding author

angela.jozala@prof.uniso.br

${ }^{1}$ LAMINFE - Laboratory of Industrial Microbiology and Fermentation Process, University of Sorocaba, Sorocaba/SP, Brazil

${ }^{2}$ Faculty of Pharmaceutical Science, University of Campinas (Unicamp), Campinas/SP, Brazil

${ }^{3}$ LAPETOX - Laboratory of Toxicological Research, University of Sorocaba, Sorocaba/SP, Brazil 


\begin{abstract}
Nisin is a $3.4 \mathrm{kDa}$ antimicrobial peptide, produced by Lactococcus lactis (ATCC 11454). This bacteriocin can inhibit spores gemination and gram-positive bacteria development and has gained visibility in therapeutic use. The bacterial cellulose (CB) has been considered an ideal material and with high quality applied in food and medicalpharmaceutical inputs. Because of all this benefits, it is important to know the system proceeding of CB with nisin. Therefore, it was realize nisin release profile analysis of CBs was performed; analysis of the minimum inhibitory concentration (MIC) of nisin against Escherichia coli ATCC 25922, Pseudomonas aeuroginosa ATCC 9721 and Staphylococus aureus ATCC 10390; antimicrobial stability test, for 100 days at different temperatures of $4^{\circ}, 25^{\circ}$ and $37^{\circ} \mathrm{C}$ against microorganisms: S. aureus e L. sakei. The results show that nisin is released by the CB in 4 hours of contact with medium and the MIC of nisin is $78 \mu \mathrm{g} / \mathrm{mL}$ for $S$. aureus, doesn't have gram-negative inhibition. It had stability until 100 days against L. sakei and 60 days for S. aureus. The system proved to be efficient and CB potentiated the antimicrobial action of nisin, acting as a selective barrier for other compounds present in the standard solution, serving as protection of the peptide at different temperatures. The CB loading system can be an ideal antimicrobial stability system for nisin.
\end{abstract}

Keywords: Bacterial cellulose, Nisin, Antimicrobial activity, Stability. 


\section{INTRODUCTION}

Antimicrobial peptides are synthesized by several organisms. Nisin is a lantibiotic, part of bacteriocins subfamily among peptides produced by microorganisms [1]. This biomolecule has 34 aminoacids and is secreted by gram-negative bacteria as Lactococcus [2-5]. Antimicrobial property of nisin is attributed to pore formation in cell membrane of microorganisms, with specific binding to the lipidic precursor of the cell wall, attached to the membrane $[2,6]$.

Nisin was considered safe by World Health Organization (WHO) and Food and Drug Administration (FDA), being used initially as a food additive [7, 8]. However, its antimicrobial action awakens potential applications for clinical use, whether in topical or systemic therapies, due to its broad spectrum against grampositive bacterial and low probability of developing microbial resistance $[8,9]$.

Nisin's application extends to several medical areas, being used in relation to mastitis, oral and gastrointestinal diseases, among [9-11]. One of the fields studied is its immobilization in solid matrices that could control its release, as for example membranes of bacterial cellulose (CB) [12].

CB is a polysaccharide extracellularly excreted by several microorganisms, such as Agrobacterium, Rhizobium, Escherichia, Sarcina e Acetobacter [13-15]. Among them Gluconacetobacter xylinus, a nonpathogenic gram-negative Acetobacter, can produce significant amounts of cellulose [16]. CB is a linear glucose polymer, formed by a matrix of nanofibers, which give it porous characteristics in a three-dimensional network structure. Although it resembles vegetable cellulose, bacterial cellulose presents a high degree of purity, crystallinity, tensile strength and high water absorption [17].

Due to its biocompatibility and non-toxicity for biological systems, CB application has been directed to medical devices and tissue engineering [18]. Due to its structural proximity to the extracellular matrix, an ideal dermal substitute is proposed, capable of inducing the direction of cells for tissue repair in tissue reconstruction $[19,20]$. Moreover its absorption characteristic facilitates exudates removal from wounds and its morphological shape helps in protecting the barrier, until epithelial healing is achieved [21, 22].

Immobilization of biomolecules in $\mathrm{CB}$ has also been studied, either by increasing its antibacterial or enzymatic, and may providing a control release system [23-25]. Although previous studies show the antimicrobial action on nisin incorporated in CB and its antioxidant capacity [26], it is necessary to investigate the stability of this system. Therefore, nisin stability after its incorporation into bacterial cellulose membranes was evaluated, aiming its future application in the development of a wound healing dressing.

\section{MATERIAL AND METHODS}

Materials

Standard nisin and bicinchoninic acid kit were purchased from Sigma-Aldrich (Sao Paulo, Brazil). All other reagents were of analytical grade.

\section{CB Production and Purification}

CBs was produced by Gluconacetobacter xylinus ATCC 53582, using 24-well plates with Hestrin \& Schramm medium. Each well was filled with $1 \mathrm{~mL}$ and incubated at $30^{\circ} \mathrm{C}$ in static condition for seven days. After formed, membranes were immersed in a $2 \%$ SDS solution under stirring overnight, washed in running water and 
bleaching process was carried out with $\mathrm{NaOH}$ for one hour until reaching $60{ }^{\circ} \mathrm{C}$. The $\mathrm{CBs}$ were washed to remove $\mathrm{NaOH}$ and sterilized at $121^{\circ} \mathrm{C}$ for 15 minutes [27].

\section{Total Proteins Quantification}

Total protein concentration was determined using bicinchoninic acid method. Bovine serum albumin (BSA) in different concentrations of 0.1 to $1 \mathrm{mg} / \mathrm{mL}$ was used as standard. Absorbance reading was performed on 96-well microplates with a wavelength of $562 \mathrm{~nm}$, by spectroscopy (Inifinite M200 PRO, RCHISTO, Austria). Each analysis was performed in triplicate, and the mean of these absorbance values was used to determine protein concentrations.

\section{Nisin Standard Curve}

The standard solution that was used in all tests for the calibration of the procedure, had $2.5 \%$ nisin in $1 \mathrm{~g}$ of the product, corresponding to an initial activity of $10^{6} \mathrm{AU} / \mathrm{mL}$. The nisin solution used had $0.25 \mathrm{mg} / \mathrm{mL}$. For the construction of the standard curve, the microorganism bioindicator of the antimicrobial activity of nisin it was Lactobacillus sakei ATCC 15521 [26, 28].

\section{Nisin Loading in CB}

The CBs membranes were disposed in 24-well plates and $1 \mathrm{~mL}$ of nisin solution $(250 \mu \mathrm{g} / \mathrm{mL})$ was added in each well. The plate was placed on shaker $\left(\mathrm{NT} 715_{2}\right.$ NovaTecnica $\_$at $30^{\circ} \mathrm{C}$ and $100 \mathrm{rpm}$ for $4 \mathrm{~h}$. After the membranes were dried at room temperature in sterile gauze.

\section{Release of Nisin from N-CB}

Nisin-loaded CB membranes (N-CB) were disposed in triplicate in 24-well plate with $1 \mathrm{~mL}$ of PBS pH 7 solution, as well as membranes without the incorporation of nisin (CB), which were used as controls. The plates were placed on shaker at $25{ }^{\circ} \mathrm{C}$ and $100 \mathrm{rpm}$. Between $2 \mathrm{~h}$ to $36 \mathrm{~h}, 1 \mathrm{~mL}$ of the samples were collected, and total protein concentration and antimicrobial activity were quantified.

\section{Microbiology Analyses}

\section{Microorganisms}

Escherichia coli ATCC 25922, Pseudomonas aeuroginosa ATCC 9721 (both representing gramnegatives) e Staphylococus aureus ATCC 10390 (representing gram-positive) were used. Tryptone Soya Broth (TSB) was used as culture medium. After growth, microorganisms were counted respecting the range of 30 to 300 colonies and selecting those with $10^{6} \mathrm{UFC} / \mathrm{mL}$ to carry out antimicrobial activity tests.

\section{Minimum Inhibitory Concentration (MIC)}

MIC method [23, 29] was adapted was adapted in 96-well microplates and performed in triplicate. The plate was stored in oven at $37{ }^{\circ} \mathrm{C}$ overnight. After this, $5 \mu \mathrm{L}$ of each well were collected and dripped into Petri dishes containing Tryptone Soya Agar (TSA) for activity analysis. The plates were kept in oven at $37^{\circ} \mathrm{C}$ overnight. 
N-CB were stored in Petri dishes at different temperatures: i) $4{ }^{\circ} \mathrm{C}$, ii) $25^{\circ} \mathrm{C}$ and iii) $37^{\circ} \mathrm{C}$, and evaluated using the agar diffusion methodology with $L$. sakei and $S$. aureus microorganisms in different time periods from 0 to 100 days, adapted from methodology [30].

\section{RESULTS AND DISCUSSION}

\section{Nisin Standard Curve}

Zone of inhibition were formed between 10.87 to $36.30 \mathrm{~mm}$, depending of solution concentrations from $0.25 \mathrm{ug} / \mathrm{mL}\left(10^{1} \mathrm{AU} / \mathrm{mL}\right)$ until $2500 \mu \mathrm{g} / \mathrm{mL}\left(10^{5} \mathrm{AU} / \mathrm{mL}\right)$. This result shows that microorganism was sensitive even when exposed to low nisin concentration, and it is important to establish the relationship between the degree of solubility and $\mathrm{pH}$ of nisin in relation to the method used [31]. As it is a soluble peptide with low molecular weight, this facilitates its diffusion and complements its antimicrobial activity [32, 33].

\section{Release of Nisin from N-CB}

Nisin release from N-CB membranes was evaluated for 36 hours (Figure 1). It was possible to observe a detachment of $580 \mu \mathrm{g} / \mathrm{mL}$ of nisin in the first 2 hours, reaching a peak of $620 \mu \mathrm{g} / \mathrm{mL}$ after $4 \mathrm{~h}$, and a plateau in $600 \mu \mathrm{g} / \mathrm{mL}$. This result shows that nisin was absorbed by CB membranes, and after 4 hours maximum release was reached and maintained, which may be used as a strategy to minimize the time of reapplications.

Figure 1. Nisin release profile from bacterial cellulose membranes in $\mathrm{PBS}$ pH 7.

Retention and consecutive release are reported in several studies with molecules and drugs, mainly with potential antimicrobials, where they try to maintain this release in a controlled manner [34]. CB provides ideal retention, with structural and functional protein stabilization, due to its nanofiber structure [24]. Cellulose membranes have also been shown to be efficient for retaining and releasing bromelain, maintaining the enzyme activity of the enzyme and providing antimicrobial activity to the final product [23]. In the literature, it is suggested a potential use of cellulose hydrogel for application and release molecules, where this release can be controlled through ultrasonic treatments [35]. Previous study with cellulose microcrystals concluded that low molecular weight molecules and drugs were faster released when compared with molecules with high molecular weight [36].

\section{Minimum Inhibitory Concentration (MIC)}

Nisin was effective to inhibit $S$. aureus growth, with MIC of $78 \mu \mathrm{g} / \mathrm{mL}$. N-CB absorbed a nisin concentration 8 times higher than MIC, which would already warrant antimicrobial activity. In the literature, the concentration of nisin with EDTA $(20 \mathrm{mM})$ is described at $125 \mu \mathrm{g} / \mathrm{mL}$, at $\mathrm{pH}$ varying between acid and base, necessary to inhibit the growth of gram-positive microorganisms [37]. Our study showed a lower MIC, however, without the use of EDTA gram-negative microorganisms, as E. coli and P. aeuruginosa, were not inhibited even in high nisin concentration $(250 \mu \mathrm{g} / \mathrm{mL})$. For this reason, the stability work was carried out only with $S$. aureus and L. sakei, the latter being used as a bioindicator of nisin antibacterial action.

Modugno et al. (2018) [38] demonstrates that nisin antimicrobial activity is favoured around neutral $\mathrm{pH}$, which our analyses were performed on. However, peptide activity can vary depending on microorganisms' type, 
as already observed in our studies. Nisin acts by interrupting transglicosylation in gram positive, causing pores formation in cell membrane and inhibits cell wall formation. On the other hand, gram-negatives bacteria have a high resistance to nisin molecule, once their outer membrane is thicker and acts preventing access of antimicrobial peptide $[38,39]$. Thus, it is necessary to unite the antimicrobial activity of nisin with EDTA, optimizing it, against gram-negatives, where EDTA will bind metal ions to lipopolysaccharide layers of bacterial membrane [37, 40].

\section{Agar diffusion and stability test}

Agar diffusion of N-CB after 7 days of storage at room temperature is shown in Figure 2.

Fig. 2 Agar diffusion in plates with CB with nisin against of microorganism L. sakei (a) and S. aureus (b)

Against L.sakei, N-CB maintained the stability during the 100 days in 4,25 and $37{ }^{\circ} \mathrm{C}$ temperatures (Figure 3). After 3 days of storage, there was an increase in nisin released by N-CB, which resulted in an increase of $1 \mathrm{AU} / \mathrm{mL}$. For the last period (100 days), there was a non-significant decrease in $\mathrm{AU} / \mathrm{mL}$ in all temperatures. It is possible that N-CB stability exceed the study period.

Initial nisin solution presented $5 \log _{10} \mathrm{AU} / \mathrm{mL}$, and after $24 \mathrm{~h}$ in contact with $\mathrm{CB}$, the N-CB system showed an increase of $1 \log _{10} \mathrm{AU} / \mathrm{mL}$ in antimicrobial activity. This fact corroborates the observation that CB may function as a filter, separating active biomolecule from other molecules in the solution and, consequently, potentiates its antimicrobial action. The same behaviour of $\mathrm{CB}$ membrane was reported during bromelain release of bromelain [23]. The process of nisin purification described in the literature showed that nisin activity can be reduced by the presence of fat clusters, salts concentration and aggregates of soluble proteins in the medium, and that after purification its antimicrobial activity was increased [41].

Figure 3. Nisin antimicrobial activity stability against L. sakei ATCC 15521 in N-CB membranes after storage at 4, 25 and $37^{\circ} \mathrm{C}$.

Antimicrobial activity against $S$. aureus was stable for 60 days at $4{ }^{\circ} \mathrm{C}$ and $25{ }^{\circ} \mathrm{C}$, with a decrease of approximately $1.5 \mathrm{log}$ representing up to 38 times less of nisin released, however, maintaining its antimicrobial activity. At $37^{\circ} \mathrm{C}$, the stability reached a period of 21 days, against the microorganism, obtaining a decay of $2 \log$, thus continuing its effectiveness.

Figure 4. Nisin antimicrobial activity stability against $S$. aureus ATCC 10390 in N-CB membranes after storage at 4,25 and $37^{\circ} \mathrm{C}$.

Staphylococci are bacteria that live on epithelial surface of humans and animals, being responsible for food poisoning and infections. Mainly referring to bacterial resistance, nisin has shown itself convenient for not presenting problematic growth of bacterial resistance when applied [7, 42]. S. aureus also appears among the main microorganisms responsible for secondary infections in burns [43,44]. Another study confers the antimicrobial capacity against the microorganism $S$. aureus, with samples supplemented with nisin, making possible a significant 
decrease of viable cells in a period of 1 day and even inhibiting biofilm formation [45]. Through the tests of nisin encapsulation in nanofiber polymer, they were able to observe that it provided stability to nisin for a period of up to seven days, however, not in a longer period, where the inhibition zone was inferior to our studies [42].

\section{CONCLUSION}

CB membranes significant incorporate nisin from a solution, and also showed a sustained release of this biomolecule for 36 hours. In addition, CB acted as a selective barrier for other compounds present in initial nisin solution, potentiating its antimicrobial action. After nisin incorporation, N-CB system was stable after storage in different conditions and can be considered an ideal system for nisin delivery. N-CB system has potential to be used as dressing in patients with skin lesions, in which nisin can be released preventing infection caused by grampositive bacteria, and $\mathrm{CB}$ may act providing a physical barrier protecting wounded area helping cell matrix regeneration.

Conflict of interest: The authors declare that there are no conflicts of interest.

Acknowledgments: The authors acknowledge financial support from Coordination for Higher Level Graduate Improvements (CAPES/Brazil, finance code 001), National Council for Scientific and Technological Development (CNPq/Brazil Process \#428751/2016-4) and the State of São Paulo Research Foundation (FAPESP/Brazil, processes \#2016/05930-4, \#2017/10789-1 and \#2018/10799-0). 


\section{REFERÊNCIAS}

1. Santos JCP, Sousa RCS, Otoni CG, Moraes ARF, Souza VGL, Medeiros EAA, Espitia PJP, Pires ACS, Coimbra JSR, Soares NFF (2018) Nisin and other antimicrobial peptides: Production, mechanisms of action, and application in active food packaging. Innov Food Sci Emerg Technol 48:179-194 . https://doi.org/10.1016/j.ifset.2018.06.008

2. Peng X, Zhu L, Wang Z, Zhan X (2020) International Journal of Biological Macromolecules Enhanced stability of the bactericidal activity of nisin through conjugation with gellan gum. Int J Biol Macromol 148:525-532 . https://doi.org/10.1016/j.ijbiomac.2020.01.164

3. Dosler S, Gerceker AA, Dosler S, Gerceker AA (2016) peptides; melittin and nisin, alone or in combination with antibiotics against Gram- positive bacteria In vitro activities of antimicrobial cationic peptides ; melittin and nisin, alone or in combination with antibiotics against Gram-positive bacteria. 9478: . https://doi.org/10.1179/1973947812Y.0000000007

4. Aldarhami A, Felek A, Sharma V, Upton M (2020) Purification and characterization of nisin P produced by a strain of Streptococcus gallolyticus. J Med Microbiol 69:605-616 . https://doi.org/10.1099/jmm.0.001170

5. Krivorotova T, Cirkovas A, Maciulyte S, Staneviciene R, Budriene S, Serviene E, Sereikaite J (2016) Nisin-loaded pectin nanoparticles for food preservation. Food Hydrocoll 54:49-56 . https://doi.org/10.1016/j.foodhyd.2015.09.015

6. Wiedemann I, Breukink E, Kraaij V, Kuipers OP, Kruijff B De, Chem JB, Wiedemann I, Breukink E, Kraaij C Van, Kuipers OP, Bierbaum G, Kruijff B De, Sahl H (2001) LIPIDS AND LIPOPROTEINS : Specific Binding of Nisin to the Peptidoglycan Precursor Lipid II Combines Pore Formation and Inhibition of Cell Wall Biosynthesis for Potent Antibiotic Activity Specific Binding of Nisin to the Peptidoglycan Precursor Lipid II C. https://doi.org/10.1074/jbc.M006770200

7. Field D, O'Connor R, Cotter PD, Ross RP, Hill C (2016) In vitro activities of nisin and nisin derivatives alone and in combination with antibiotics against Staphylococcus biofilms. Front Microbiol 7:1-11 . https://doi.org/10.3389/fmicb.2016.00508

8. de Arauz LJ, Jozala AF, Mazzola PG, Vessoni Penna TC (2009) Nisin biotechnological production and application: a review. Trends Food Sci Technol 20:146-154 . https://doi.org/10.1016/j.tifs.2009.01.056

9. Nguyen T, Brody H, Lin GH, Rangé H, Kuraji R, Ye C, Kamarajan P, Radaic A, Gao L, Kapila Y (2020) Probiotics, including nisin-based probiotics, improve clinical and microbial outcomes relevant to oral and systemic diseases. Periodontol 2000 82:173-185 . https://doi.org/10.1111/prd.12324

10. Kitazaki K, Koga S, Nagatoshi K, Kuwano K, Zendo T, Nakayama J, Sonomoto K, Ano H, Katamoto H (2017) In vitro synergistic activities of cefazolin and nisin a against mastitis pathogens. J Vet Med Sci 79:1472-1479 . https://doi.org/10.1292/jvms.17-0180

11. Sandiford SK (2019) Current developments in lantibiotic discovery for treating Clostridium difficile infection. Expert Opin Drug Discov 14:71-79 . https://doi.org/10.1080/17460441.2019.1549032

12. Bayazidi P, Almasi H, Asl AK (2018) Immobilization of lysozyme on bacterial cellulose nanofibers: Characteristics, antimicrobial activity and morphological properties. Int J Biol Macromol 107:25442551 . https://doi.org/10.1016/j.ijbiomac.2017.10.137

13. Gromovykh TI, Pigaleva MA, Gallyamov MO, Ivanenko IP, Ozerova KE, Kharitonova EP, Bahman M, 
Feldman NB, Lutsenko S V., Kiselyova OI (2020) Structural organization of bacterial cellulose: The origin of anisotropy and layered structures. Carbohydr Polym 237:116140 .

https://doi.org/10.1016/j.carbpol.2020.116140

14. Hassan E, Abdelhady H, Abd 1-Salam S, Abdullah S (2015) The Characterization of Bacterial Cellulose Produced by Acetobacter xylinum and Komgataeibacter saccharovorans under Optimized Fermentation Conditions. Br Microbiol Res J 9:1-13 . https://doi.org/10.9734/bmrj/2015/18223

15. Huang Y, Zhu C, Yang J, Nie Y, Chen C, Sun D (2014) Recent advances in bacterial cellulose. Cellulose 21:1-30 . https://doi.org/10.1007/s10570-013-0088-Z

16. Wang P, Wang H, Zhao X, Li L, Chen M, Cheng J, Liu J, Li X (2019) Antibacterial activity and cytotoxicity of novel silkworm-like nisin@PEGylated MoS2. Colloids Surfaces B Biointerfaces 183:110491 . https://doi.org/10.1016/j.colsurfb.2019.110491

17. Costa AFS, Almeida FCG, Vinhas GM, Sarubbo LA (2017) Production of bacterial cellulose by Gluconacetobacter hansenii using corn steep liquor as nutrient sources. Front Microbiol 8:1-12 . https://doi.org/10.3389/fmicb.2017.02027

18. Zhang C, Cao J, Zhao S, Luo H, Yang Z, Gama M, Zhang Q, Su D, Wan Y (2020) Biocompatibility evaluation of bacterial cellulose as a scaffold material for tissue-engineered corneal stroma. Cellulose 27:2775-2784 . https://doi.org/10.1007/s10570-020-02979-0

19. de Oliveira Barud HG, da Silva RR, da Silva Barud H, Tercjak A, Gutierrez J, Lustri WR, de Oliveira OB, Ribeiro SJL (2016) A multipurpose natural and renewable polymer in medical applications: Bacterial cellulose. Carbohydr Polym 153:406-420 . https://doi.org/10.1016/j.carbpol.2016.07.059

20. Numata Y, Mazzarino L, Borsali R (2015) A slow-release system of bacterial cellulose gel and nanoparticles for hydrophobic active ingredients. Int J Pharm 486:217-225 .

https://doi.org/10.1016/j.ijpharm.2015.03.068

21. Portela R, Leal CR, Almeida PL, Sobral RG (2019) Bacterial cellulose: a versatile biopolymer for wound dressing applications. Microb Biotechnol 12:586-610 . https://doi.org/10.1111/1751-7915.13392

22. Khalid A, Ullah H, Ul-Islam M, Khan R, Khan S, Ahmad F, Khan T, Wahid F (2017) Bacterial cellulose-TiO2 nanocomposites promote healing and tissue regeneration in burn mice model. RSC Adv 7:47662-47668 . https://doi.org/10.1039/c7ra06699f

23. Ataide JA, De Carvalho NM, Rebelo MDA, Chaud MV, Grotto D, Gerenutti M, Rai M, Mazzola PG, Jozala AF (2017) Bacterial Nanocellulose Loaded with Bromelain: Assessment of Antimicrobial, Antioxidant and Physical-Chemical Properties. Sci Rep 7:2-10 . https://doi.org/10.1038/s41598-017$18271-4$

24. Malheiros PS, Jozala AF, Pessoa-Jr. A, Vila MMDC, Balcão VM, Franco BDGM (2018) Immobilization of antimicrobial peptides from Lactobacillus sakei subsp. sakei 2a in bacterial cellulose: Structural and functional stabilization. Food Packag Shelf Life 17:25-29 . https://doi.org/10.1016/j.fpsl.2018.05.001

25. Yu B, Cheng H, Zhuang W, Zhu CJ, Wu J, Niu H, Liu D, Chen Y, Ying H (2019) Stability and repeatability improvement of horseradish peroxidase by immobilization on amino-functionalized bacterial cellulose. Process Biochem 79:40-48 . https://doi.org/10.1016/j.procbio.2018.12.024

26. dos Santos CA, dos Santos GR, Soeiro VS, dos Santos JR, Rebelo M de A, Chaud MV, Gerenutti M, Grotto D, Pandit R, Rai M, Jozala AF (2018) Bacterial nanocellulose membranes combined with nisin: a 
strategy to prevent microbial growth. Cellulose 25:6681-6689 . https://doi.org/10.1007/s10570-0182010-1

27. Jozala AF, Pértile RAN, dos Santos CA, de Carvalho Santos-Ebinuma V, Seckler MM, Gama FM, Pessoa A (2014) Bacterial cellulose production by Gluconacetobacter xylinus by employing alternative culture media. Appl Microbiol Biotechnol 99:1181-1190 . https://doi.org/10.1007/s00253-014-6232-3

28. De Arauz LJ, Jozala AF, Baruque-Ramos J, Mazzola PG, Júnior AP, Penna TCV (2012) Culture medium of diluted skimmed milk for the production of nisin in batch cultivations. Ann Microbiol 62:419-426 . https://doi.org/10.1007/s13213-011-0278-6

29. Mazzola PG, Jozala AF, Novaes LCDL, Moriel P, Penna TCV (2009) Minimal inhibitory concentration (MIC) determination of disinfectant and/or sterilizing agents. Brazilian J Pharm Sci 45:241-248 . https://doi.org/10.1590/S1984-82502009000200008

30. Correia RC, Jozala AF, Martins KF, Penna TCV, Duek EA de R, Rangel-Yagui C de O, Lopes AM (2015) Poly(lactic-co-glycolic acid) matrix incorporated with nisin as a novel antimicrobial biomaterial. World J Microbiol Biotechnol 31:649-659 . https://doi.org/10.1007/s11274-015-1819-0

31. Goudarzi F, Asadi A, Afsharpour M, Jamadi RH (2018) In Vitro Characterization and Evaluation of the Cytotoxicity Effects of Nisin and Nisin-Loaded PLA-PEG-PLA Nanoparticles on Gastrointestinal (AGS and KYSE-30), Hepatic (HepG2) and Blood (K562) Cancer Cell Lines. AAPS PharmSciTech 19:15541566 . https://doi.org/10.1208/s12249-018-0969-4

32. Niaz T, Imran M (2021) Diffusion kinetics of nisin from composite coatings reinforced with nanorhamnosomes. J Food Eng 288:110143 . https://doi.org/10.1016/j.jfoodeng.2020.110143

33. Azhar NS, Zin NH, Haziyamin T, Abdul T (2017) Lactococcus Lactis Strain A5 Producing Nisin-like Bacteriocin Active against Gram Positive and Negative Bacteria Driven by the increasing demand for animal protein and food security, aquaculture is a fast growing industry that becomes a vital economy in. Trop Life Sci Res 28:107-118

34. Vismara E, Bernardi A, Bongio C, Farè S, Pappalardo S, Serafini A, Pollegioni L, Rosini E, Torri G (2019) Bacterial Nanocellulose and Its Surface Modification by Glycidyl Methacrylate and Ethylene Glycol Dimethacrylate . Incorporation of Vancomycin and Ciprofloxacin. 1-22 . https://doi.org/10.3390/nano9121668

35. Yan L, Wang L, Gao S, Liu C, Zhang Z, Ma A, Zheng L (2019) Celery cellulose hydrogel as carriers for controlled release of short-chain fatty acid by ultrasound. Food Chem 125717 . https://doi.org/10.1016/j.foodchem.2019.125717

36. Dong Y, Paukkonen H, Fang W, Kontturi E, Laaksonen T, Laaksonen P (2018) Entangled and colloidally stable microcrystalline cellulose matrices in controlled drug release. Int J Pharm. https://doi.org/10.1016/j.ijpharm.2018.06.022

37. Khan A, Dang K, Riedl B, Lacroix M (2015) LWT - Food Science and Technology Optimization of the antimicrobial activity of nisin, Na-EDTA and $\mathrm{pH}$ against gram-negative and gram-positive bacteria. LWT - Food Sci Technol 61:124-129 . https://doi.org/10.1016/j.lwt.2014.11.035

38. Modugno C, Loupiac C, Bernard A, Jossier A, Neiers F (2018) E ff ect of high pressure on the antimicrobial activity and secondary structure of the bacteriocin nisin. Innov Food Sci Emerg Technol 47:9-15 . https://doi.org/10.1016/j.ifset.2018.01.006 
39. Gut IM, Prouty AM, Ballard JD, Wilfred A, Donk V Der, Blanke SR, Gut IM, Prouty AM, Ballard JD, Donk WA Van Der, Blanke SR (2008) Inhibition of Bacillus anthracis Spore Outgrowth by Nisin Inhibition of Bacillus anthracis Spore Outgrowth by Nisin $\square .52$ : . https://doi.org/10.1128/AAC.0062508

40. Norhana MNW, Poole SE, Deeth HC, Dykes GA (2012) Effects of nisin, EDTA and salts of organic acids on Listeria monocytogenes, Salmonella and native micro fl ora on fresh vacuum packaged shrimps stored at 4 C. Food Microbiol 31:43-50 . https://doi.org/10.1016/j.fm.2012.01.007

41. Jozala AF, De Lencastre Novaes LC, Mazzola PG, Oliveira-Nascimento L, Vessoni Penna TC, Teixeira JA, Passarinha LA, Queiroz JA, Pessoa A (2015) Low-cost purification of nisin from milk whey to a highly active product. Food Bioprod Process 93:115-121 . https://doi.org/10.1016/j.fbp.2013.12.003

42. Han D, Sherman S, Filocamo S, Steckl AJ (2017) Long-term antimicrobial effect of nisin released from electrospun triaxial fiber membranes. Acta Biomater 53:242-249.

https://doi.org/10.1016/j.actbio.2017.02.029

43. Oliveira FL, Serra MC do VF (2011) Infecções em queimaduras: revisão. Rev Bras Queimaduras 10:9699

44. Macedo, J, Santos, J. 2001. Complicações infecciosas em pacientes queimados. Revista Brasileira de Cirurgia Plástica 21(2): 108-111.

45. de Oliveira Junior AA, de Araújo Couto HGSA, Barbosa AAT, Carnelossi MAG, de Moura TR (2015) Stability, antimicrobial activity, and effect of nisin on the physico-chemical properties of fruit juices. Int $\mathbf{J}$ Food Microbiol 211:38-43 . https://doi.org/10.1016/j.ijfoodmicro.2015.06.029 